\title{
O feminismo marxista e a demanda pela socialização do trabalho doméstico e do cuidado com as crianças
}

Marxist feminism and the demand for the socialization of domestic labor and child care

No cerne do movimento socialista, o debate acerca do trabalho doméstico e do cuidado com as crianças assumiu diferentes contornos. Até o século XX, a concepção de que a mulher deveria ocupar seu lugar "natural" na esfera privada, assumindo o papel de mãe, cuidadora e dona de casa, predominava nas organizações operárias, sendo parte integrante de seu discurso anticapitalista. Esta posição defendida por inúmeros organismos partidários e sindicais refletia a preocupação crescente diante da substituição massiva da mão de obra adulta masculina pela feminina e infantil, que conduziria ao decréscimo generalizado dos salários ocasionado não só pela introdução de novas reservas de trabalhadores cujo trabalho é depreciado, como pela equiparação do valor da força de trabalho ao tempo de trabalho necessário para a manutenção e reprodução do trabalhador individual, e não de sua família.

Pierre-Joseph Proudhon (1809-1865) foi um dos principais opositores à inclusão das mulheres nos meios operários, reagindo fortemente contra as tentativas de sua caracterização como trabalhadoras. Em seu livro $A$ pornocracia, ou as mulheres nos tempos modernos, escrito em 1858, quando de seu exílio na Bélgica, Proudhon descreve as mulheres como seres de inferioridade irremediável, equivalentes a $2 / 3$ de um homem. De acordo com ele, os homens teriam maior potencial físico e intelectual por terem

É professora de Sociologia no Instituto Federal do Triângulo Mineiro - campus Uberlândia. E-mail: <joanaeljaick@yahoo.com.br>. 
cérebros diferenciados, o que os tornaria aptos a desempenhar funções públicas. Já as mulheres, como "rainhas do lar", discípulas, donas de casa e mães, deveriam ser relegadas aos assuntos domésticos, próprios à sua frágil constituição física e mente limitada.

Quanto às coisas do exterior, eu não as quis, eu não as quero para a mulher, e pelas mesmas considerações, a guerra, porque a guerra se adéqua pouco à beleza como também à servidão. Eu não quero a política, porque a política é a guerra. Eu não quero qualquer função jurídica, policial ou governamental, porque é sempre a guerra. Eu digo que o reinado da mulher está na família (Proudhon, 1858, p. 12-13; tradução da autora).

Contudo, os brados de Proudhon para a manutenção das mulheres dentro de casa não significam que ele estivesse cego à empreitada iniciada pelas mulheres trabalhadoras no interior dos organismos de classe. Pelo contrário, sua cólera derivava justamente da observação de que elas passavam a ocupar espaços cada vez maiores, fosse no trabalho fosse na política. Isto pode ser visto em sua reprovação ao "banquete fraterno" promovido por mulheres socialistas francesas para exigir reformas e apoiar candidatos políticos, em dezembro de 1848:

O papel das mulheres não está na vida exterior, na vida ativa e na agitação, mas na vida íntima, nos sentimentos e na tranquilidade do lar. O socialismo não veio apenas para restaurar o trabalho, mas também para reabilitar o lar, santuário da família, símbolo da união matrimonial (Proudhon apud Scott, 2002, p. 137).

Assim como Proudhon, o historiador francês Jules Michelet condenou a mudança no papel social das mulheres. Em seu livro A mulher, publicado originalmente em 1859, no qual se dedica à análise da condição feminina, Michelet (1995) recorre a estudos científicos para justificar a inferioridade biológica e anatômica das mulheres e sua consequente incapacidade de atuar como sujeitos históricos. De acordo com sua visão, as mulheres seriam naturalmente debilitadas física e intelectualmente pelas menstruações e gestações. Sua biologia determinaria o papel a ser ocupado por elas, isto é, de seres fixados ao lar, dependentes de seus maridos. Como "eternas doentes", elas não seriam apropriadas para o trabalho fora de casa. Sua 
fraqueza e sofrimento ditariam que elas precisam ser cuidadas e poupadas, de modo que o trabalho as debilitaria, desgastaria e corromperia ainda mais, degenerando as futuras gerações e destruindo a família.

Dispensadas da profissão e da especialidade, as mulheres guardariam para o homem um "tesouro de nobreza e rejuvenescimento". Já quando levadas ao trabalho, desviariam de sua natureza e de seu papel verdadeiro de "mães". Isto poderia ser percebido nas cidades, onde as mulheres seriam contaminadas pela corrupção moral e vícios, tornando-se coquetes, ávidas de luxo, frívolas, retrógradas, adúlteras ou prostitutas. Submetidas à pobreza e ao trabalho excessivo nas cidades, elas tenderiam à loucura ou à criminalidade. Como operárias, seriam causa de desordem política e moral, além de discórdia conjugal.

Barbárie de nosso Ocidente! A mulher já não é levada em conta para o amor, para a felicidade do homem, menos ainda como maternidade e como potência da raça; mas como operária! A operária! Palavra ímpia, sórdida, como nenhuma língua jamais teve, como nenhum tempo teria compreendido antes desta idade do ferro, e que sozinha derrubaria todos os nossos pretensos progressos (Michelet, 1995, p. 14-15).

Mas, ao mesmo tempo que ele considera as mulheres motivo de desordem social, procura reforçar a imagem de que seriam frágeis e passivas. Para conciliar sua perspectiva dúplice acerca do caráter da mulher, Michelet, assim como muitos pensadores a ele contemporâneos, passava a classificar as mulheres populares rebeldes - que apareciam como fonte de insurgência e contestação - como doentes mentais, destarte, exceções à sua própria natureza.

A negação da identificação das mulheres como "trabalhadoras" representava ainda uma forte reação à ruptura com os valores tradicionais. Como destacara o historiador Peter Gay (2001), a ideologia vitoriana, que valorizava "o poderoso sexo frágil", procurava restabelecer os papéis sexuais tradicionais e a rígida separação entre o público e o privado. Mas, se as mulheres das classes burguesas passavam a recolher-se em casa, circulando ocasionalmente nos salões de chá, nos magazines, na igreja e nos clubes de caridade, as mulheres trabalhadoras foram menos afetadas pelo confinamento doméstico. A necessidade de complementar a renda familiar - fosse através do trabalho industrial, fosse por meio de atividades comerciais, como a venda em bancas e cestos, a realização 
de faxinas, lavagem de roupas e trabalhos de costura para fora, o cuidado de crianças como amas-de-leite ou babás, a entrega de recados e mercadorias, ou a prostituição - exigia que as mulheres do povo saíssem às ruas e fragmentassem seu tempo entre tarefas domésticas e atividades suplementares. Desse modo, as mulheres transitavam incansavelmente pelos canteiros de obras, oficinas, mercados, margens de rios e lavadouros, criando laços de sociabilidade feminina e formas de expressão próprias, marcadas pela irreverência, ironia, espontaneidade e subversão (Perrot, 2006, p. 190).

Assim, coube, sobretudo, às mulheres trabalhadoras dos séculos XIX e XX, o rompimento com a perspectiva que as mantinha atreladas ao lar e ao papel de mães, e que considerava a família "um santuário necessário em um mundo organizado ao redor dos princípios impessoais do mercado", não influenciada por "forças socioeconômicas impessoais" (Lasch, 1999, p. 178). Como afirmara Rosa Luxemburgo, a luta de classes proletária ampliou os horizontes das mulheres trabalhadoras, "tornando suas mentes flexíveis, desenvolvendo seu pensamento e apontando para o grande objetivo a que deveriam dirigir seus esforços" (Luxemburgo, 1912; tradução da autora). O socialismo teria conseguido proporcionar o afloramento da massa de mulheres proletárias, que implicaria o questionamento da posição ocupada pela mulher na sociedade burguesa, a ruptura com os valores tradicionais religiosos e patriarcais, a rejeição da moral burguesa, o reconhecimento de seu direito de voto, associação e expressão, o anseio pela conquista de sua independência econômica e a luta pela construção de sua individualidade, por meio de seu livre desenvolvimento intelectual e profissional. Sob essa nova perspectiva, o trabalho doméstico e o cuidado com as crianças, antes concebidos como atributos naturais da mulher, passam a ser vistos como empecilhos à sua participação na vida pública através das atividades laborativas e políticas.

\section{A contribuição de Marx e Engels para a análise do trabalho doméstico e do cuidado com as crianças sob o capitalismo}

Embora muitas críticas tenham sido direcionadas a Marx e Engels - por supostamente menosprezarem a importância do trabalho doméstico para a produção social, ao caracterizarem-no como "improdutivo", idealizarem a família proletária como instância livre da influência de interesses materiais ou, ainda, ao subsumirem as relações hierárquicas entre homens e mulheres à questão da exploração de classe -, gerações de feministas marxistas 
procuraram embasar suas críticas ao patriarcado no materialismo histórico, por este oferecer um arsenal teórico capaz de problematizar e historicizar as categorias, relações e instituições sociais.

A ruptura com o hegelianismo foi o passo fundamental que permitiu a Marx a construção teórica de uma contundente crítica à cisão entre as esferas pública e privada, reproduzida pelos pensadores modernos. Tal cisão confinava as mulheres ao espaço doméstico e reservava exclusivamente ao homem o status de cidadão, dotado de virtudes cívicas indispensáveis à moralidade pública.

Segundo Hegel, os homens, como proprietários e representantes da família, aproximam-se do mundo exterior e da consciência da universalidade. Para eles, portanto, a cisão entre os diferentes domínios sociais não é absoluta e incontornável, posto que encontram-se imersos em uma relação recíproca e dialética com a comunidade política. Quanto às mulheres, estas seriam naturalmente inaptas para atividades que demandam a faculdade racional e criativa - como as ciências mais avançadas, a filosofia e certas formas de produção artística -, sendo absorvidas completamente na particularidade da família (Hegel, 1997 [1821]).

Sendo assim, para Hegel, as mulheres poderiam ter ideias felizes, gostos e elegância, mas não conseguiriam desenvolver o pensamento conceitual e a autoconsciência. Somente a personalidade masculina seria capaz de evoluir à pessoa legal com direitos e deveres, justamente por experienciar a fragmentação de seu pensamento entre a inclinação individual e a escolha racional. A natureza cindida da mente masculina permitiria aos homens a ação e influência sobre o mundo exterior, na medida em que é no conflito com o mundo externo que buscam superar sua divisão interna. Dessa forma, os homens têm sua verdadeira vida substantiva no Estado, encontrando na esfera pública a possibilidade de realização dos objetivos universais da ação racional, pela participação política.

Enquanto a família permanece para o homem como um refúgio, no âmbito do qual ele vive uma vida subjetiva e ética no plano dos sentimentos, na vida feminina ela assume um significado diferente. Enclausurada na família, a mente uniforme e homogênea da mulher se ocuparia apenas de reproduzir os valores tradicionais da vida ética familiar. A "devoção familiar", que domina sua mente, tornaria a mulher uma inimiga da comunidade política, impossibilitando-a de tomar decisões em prol da coletividade. 
Voltadas para a individualidade e presas às suas vontades substantivas e sentimentos concretos, as mulheres regulariam suas ações não pelas demandas de universalidade, mas por paixões particulares, opiniões arbitrárias e interesses familiares. Diferentemente dos homens, cuja autoconsciência individual vê-se dissolvida na universalidade, a mulher mostrar-se-ia incapaz de transcender a comunidade ética natural.

Como seres incapazes de autodesenvolvimento, as mulheres estariam, definitivamente, destinadas à maternidade e à administração do lar. Todas as atividades humanas que afastariam os indivíduos do instinto natural, em direção à autodeterminação e realização da liberdade - isto é, o trabalho, a luta e a filosofia -, seriam vedadas às mulheres. Por não considerar que as mulheres exerçam trabalhos na esfera doméstica, Hegel consideraas excluídas igualmente da sociedade civil, não podendo aproveitarse dos efeitos liberalizantes do trabalho, suscitados pela conversão das necessidades naturais em necessidades sociais.

Esse raciocínio leva Hegel a recorrer a uma polêmica analogia, que equipara a diferenciação entre homens e mulheres à diferenciação existente entre os animais e as plantas. Os homens corresponderiam a animais, já que seriam forçados a se opor à natureza exterior a eles próprios, estando imiscuídos em uma série de conflitos e contradições que engendraria um processo de diferenciação mais sofisticado no domínio do espírito. As mulheres, por sua vez, corresponderiam a plantas, apresentando um desenvolvimento mais plácido, de dentro para fora, permanecendo incompletas, presas nos processos repetitivos e não dirigidos da diferenciação natural. A justificativa para a exclusão das mulheres da esfera pública repousaria, enfim, na diferenciação natural, entendida como aspecto de sua complementaridade biológica. Ao trilhar esse caminho, Hegel passa então a aderir a argumentos naturalizantes e essencialistas, tão rechaçados pelo autor na defesa de sua teoria da história.

A crítica ao pensamento de Hegel formulada por Marx não se mostrou indiferente a essas contradições. Desde seus primeiros escritos no Rheinische Zeitung, Marx apontava os equívocos cometidos por Hegel ao recair em concepções a-históricas de natureza humana e em uma diferenciação fixa e imutável entre homens e mulheres.

Em “A questão judaica”, ensaio escrito em 1844, Marx apresenta uma desconstrução radical da perspectiva hegeliana que enxerga a esfera 
pública como força unificadora da razão e da liberdade, e o Estado como paradigma moral e objetivação do espírito universal (Marx, 1969). Nesta obra, ele questiona duramente a cisão da ordem social em diferentes domínios - família (reprodução), economia (produção material) e política (regulação) -, que tem por consequência a redução do espaço de confinamento da mulher. Já em seus "Manuscritos econômico-filosóficos", de 1844, Marx observa que, "com as transformações no organismo do trabalho, coube, portanto, ao sexo feminino um novo círculo de afazeres (Erwerbstätigkeit) [...] as mulheres [ocupando] uma posição economicamente mais autônoma... ambos os sexos aproximados um do outro nas suas relações sociais". Ao mesmo tempo, demonstra preocupação com as condições enfrentadas pelas trabalhadoras nas tecelagens inglesas e com a crescente "prostituição da carne não proprietária sob todas as formas" (Marx, 2004b, p. 33-34).

Utilizando dados empíricos, Engels (2008), em sua obra A situação da classe trabalhadora na Inglaterra (de 1844), percorre itinerário teórico semelhante, ao examinar a progressiva eliminação do homem adulto da fábrica, mediante o crescente emprego das máquinas na produção industrial da cidade de Manchester. Assim, infere que, quanto mais a atividade braçal e os esforços musculares fossem substituídos pela força hidráulica ou do vapor, tanto menos se necessitaria de homens. Como resultado, os homens seriam substituídos por mulheres e crianças que, além de serem mais hábeis, receberiam salários menores.

A entrada das mulheres no trabalho industrial daria ensejo à proliferação de uma série de doenças físicas e mentais, que elevariam também a mortalidade infantil e o número de abortos. No entanto, Engels adverte que as precárias condições de trabalho não seriam encontradas exclusivamente nas fábricas, sendo as pequenas oficinas uma das grandes responsáveis pela morte prematura de mulheres. Nestas, as trabalhadoras viveriam, comeriam e dormiriam no próprio local de trabalho, sendo "completamente escravizadas pelos patrões". Desse modo, "essas infelizes moças, submetidas ao chicote moral da escravidão moderna, que é a ameaça do despedimento, são obrigadas a um trabalho tão contínuo e fatigante que nenhum homem robusto suportaria" (Engels, 2008, p. 242).

De acordo com Engels, essa nova conformação da classe operária produziria também efeitos absolutamente negativos sobre a família, promovendo 
sua desestruturação e a subversão dos valores morais tradicionais, sobretudo das novas gerações.

A consequência necessária é a subversão da ordem existente, que, precisamente porque é imposta, tem implicações deletérias para os operários. Sobretudo, o trabalho das mulheres desagrega completamente a família - com a mulher trabalhando diariamente doze ou treze horas na fábrica, e com o homem também ocupado, na mesma fábrica ou em outro lugar, quais podem ser os resultados para as crianças? Crescem sem cuidados, como ervas daninhas, são entregues à guarda alheia por 1 shilling ou 1,5 shilling por semana - e pode-se imaginar qual o tratamento que lhes é reservado (Engels, 2008, p. 181).

Assim, dentre as sequelas associadas ao ingresso das mulheres na indústria, Engels dá considerável destaque às "nefastas" consequências morais, que atingiriam os cônjuges e as crianças. A entrada de jovens solteiras nas fábricas, por exemplo, torná-las-ia desfamiliarizadas com as tarefas domésticas, sendo "completamente inexperientes e incapazes de se tornarem boas donas de casa. Não sabem costurar, cozinhar ou lavar, desconhecem as atividades mais elementares da vida doméstica e ignoram totalmente como lidar com crianças" (Engels, 2008, p. 242).

Além do desconhecimento dos "deveres da vida familiar", as jovens estariam mais propensas a se casar precoce e levianamente, devido à inevitável e compulsória proximidade física de ambos os sexos e de diferentes idades no local de trabalho. $\mathrm{O}$ ambiente da fábrica, portanto, onde proliferariam costumes e linguagem indecentes, não constituiria certamente as condições mais indicadas para o "desenvolvimento do caráter feminino" (Engels, 2008, p. 186). A falta de orientação no lar e a precária formação intelectual e moral das mulheres também seriam fatores de estímulo à promiscuidade, isto é, de adesão às relações sexuais precoces e desregradas, à prostituição juvenil, à imoralidade e aos costumes "deploráveis". Por conseguinte, a exploração brutal do trabalho feminino tornaria as mulheres incapacitadas para as tarefas domésticas, levando ao abandono da casa e dos filhos. Esse novo modo de vida produziria, assim, uma indiferença e até mesmo uma hostilidade em face da vida familiar, aproximando-as da degradação moral. Os efeitos desagregadores do trabalho feminino decorreriam, inclusive, da progressiva independência econômica da esposa e dos filhos dos operários, que levariam à debilitação da autoridade paterna e, por fim, à "destruição da família". 
A mãe que não tem tempo para ocupar-se do filho, que em seus primeiros anos não pode dedicar-lhe os cuidados mais elementares, que mal pode vê-lo, não pode ser para ele uma verdadeira mãe: torna-se-lhe indiferente, trata-o sem amor e solicitude, como a uma criança estranha. Por seu turno, crianças que crescem nessas condições mais tarde serão incapazes de vida familiar, não se sentirão à vontade na família que vierem a constituir porque conheceram apenas uma vida solitária - e acabarão contribuindo para a destruição da família, fenômeno já comum entre os operários ingleses (Engels, 2008, p. 182).

O sinal mais claro de que a família estaria em processo de "destruição" seria sua desorganização interna, marcada pela inversão dos papéis nas relações familiares. Os homens, sobrepujados pela competição no mercado de trabalho e "condenados ao trabalho doméstico" - o "mau trabalho" -, se encontrariam emasculados, atingidos em sua virilidade. Já as mulheres ver-se-iam despidas de sua feminilidade, sem, no entanto, assumirem totalmente as características viris masculinas. A "subversão na situação dos sexos", portanto, promoveria a confusão de suas identidades sexuais. Assim, homens e mulheres, numa posição "falsa" e "artificial" diante do outro, testemunhariam a degradação de sua própria humanidade.

Em muitos casos, a família não se desagrega com o trabalho da mulher, mas se desorganiza: é a mulher que mantém a casa, o homem desempregado cuida das crianças e da vida doméstica. Isso é muito frequente: em Manchester, contam-se às centenas os homens condenados ao trabalho doméstico. É fácil imaginar a justificada exasperação provocada nesses operários por essa emasculação de fato e seus resultados na inversão das relações familiares, tanto mais quanto as outras relações sociais permanecem inalteradas (Engels, 2008, p. 183).

A abjeção de Engels à troca de papéis sociais no âmbito do trabalho e da família é explicitada em seus comentários à carta de um operário inglês, na qual este relata a experiência de outro operário:

Veja bem: remendava as meias de sua mulher com agulha e fio e, quando viu seu velho amigo entrar, tentou esconder o que fazia, mas Joe, assim se chamava seu amigo, viu tudo e perguntou: "Jack, que diabo, que estás fazendo, onde está tua mulher? É este teu trabalho?". E o pobre Jack teve vergonha e disse: “Não, sei bem que este não é meu trabalho, mas minha pobre mulher está na fábrica, tem de sair às 5 h30 da manhã e trabalha até às $8 \mathrm{~h}$ da noite, e quando chega à casa está tão cansada que não pode fazer 
nada e tenho de fazer o que puder no lugar dela, porque não tenho trabalho, procuro trabalho há três anos e não encontro, e não encontrarei pelo resto da vida”. E depois deixou cair uma lágrima. "[...] Eu nunca acreditei que tu ou outro pudesse me ver remendando as meias da minha mulher, porque isso é um mau trabalho, mas veja que ela quase não se aguenta em pé. Eu tenho medo que ela adoeça e depois não sei o que acontecerá com a gente. Há muito tempo é ela que mantém a família e eu é que sou a mulher; é um mau trabalho, Joe", e chorava amargamente dizendo: "Nem sempre foi assim" [...] Tínhamos uma boa casa com móveis e Mary não precisava trabalhar, eu podia trabalhar pelos dois, mas o mundo mudou e Mary tem de trabalhar e eu tenho de ficar aqui, cuidar das crianças e cozinhar, porque quando a pobre chega em casa está esgotada” (Engels, 2008, p. 183).

Diante do caso narrado, Engels adere ao sentimento de indignação exposto pelo operário, colocando em questão os supostos avanços e conquistas da "civilização", que afastariam os seres humanos de sua "verdadeira” humanidade. A "subversão" das atribuições de cada sexo conduziria a uma situação "paradoxal e absurda", na qual o caráter verdadeiramente viril do homem e a verdadeira feminilidade da mulher seriam tolhidos de modo degradante e infamante, produzindo resultados escarnecedores. Nesse sentido, Engels reproduz nessa obra a concepção sexista tradicional dos papéis sociais atribuídos a homens e mulheres, lamentando o distanciamento das mulheres em relação a seus afazeres "naturais" no lar, na maternidade e nos cuidados com o marido. Sua nostalgia em relação aos paradigmas familiares pré-industriais torna-se aspecto relevante de sua crítica à sociedade burguesa, ainda pouco desenvolvida naquele momento.

Há que se ressaltar, no entanto, que, de acordo com Engels, a retomada dos papéis tradicionais de ambos os sexos não implicaria necessariamente o restabelecimento da supremacia masculina sobre a mulher, considerada por ele como desumana. Em lugar de uma comunidade familiar organizada em função da participação de seus membros na aquisição dos bens comuns da família, isto é, do interesse privado, Engels aponta a necessidade de uma comunidade familiar "verdadeira e racional", ancorada no amor familiar, que constituiria seu vínculo substantivo. Assim, vemos como Engels, tal como Marx, inicialmente associava a família à "comunidade ética", preocupando-se com o seu resgate da deturpação promovida pelo predomínio dos interesses particulares e pela ânsia individualista.

A parceria entre Engels e Marx será de profunda relevância para a superação do discurso idealista, baseado na argumentação moral. A primeira grande 
obra realizada a partir dessa cooperação, A sagrada família (de 1844), sinaliza a mudança de postura de ambos, no tocante à crítica da família. Embora abordem os "aspectos desumanos da situação geral da mulher na sociedade de hoje” (Marx e Engels, 2003 [1844], p. 218) - destacando a desonra moral, o adultério e a sedução -, já conferem maior peso ao entendimento das relações entre os sexos como historicamente determinadas. Abre-se, então, espaço para a compreensão das causas históricas da opressão feminina, em lugar de aceitá-la como fato naturalmente dado, inscrito na "feminilidade" ou "masculinidade" humana.

Em trabalhos subsequentes, como $A$ ideologia alemã, escrito por eles em 1845-1846, Marx e Engels remontarão às origens da divisão sexual do trabalho, estabelecendo que "a escravidão na família, embora ainda tosca e latente", teria sido a primeira propriedade. Apesar de avançarem na questão, os autores ainda partiam do pressuposto, no entanto, de que a divisão "natural" do trabalho na família, que resulta na distribuição quantitativa e qualitativamente desigual do trabalho e de seus produtos, teria um fundo biológico, calcado na diferenciação de funções reprodutivas. Cabe lembrar que esta fundamentação da divisão do trabalho é igualmente retomada em $O$ capital (livro 1, capítulo XII, seção 4), quando Marx discute os antecedentes da divisão do trabalho dentro da manufatura e da sociedade.

Dentro de uma família, e com desenvolvimento ulterior dentro de uma tribo, origina-se uma divisão do trabalho que evolui naturalmente das diferenças de sexo e de idade, portanto sobre uma base puramente fisiológica, que amplia seu material com a expansão da comunidade, com o crescimento da população e notadamente com o conflito entre as diversas tribos e a subjugação de uma tribo pela outra (Marx, 1985 [1967], p. 277).

Não obstante as incongruências evidenciadas no pensamento de Marx e Engels no tocante às mulheres, o complexo processo histórico capaz de forjar uma identidade feminina "proletária" aproveitou-se enormemente de suas contribuições teóricas. A descrição das condições de vida das operárias e dos efeitos sociais da substituição da mão de obra masculina pela feminina e infantil colaborou para a consolidação de uma nova imagem feminina associada às "mulheres proletárias". Esse empreendimento representou uma mudança significativa na concepção do papel desempenhado pelas mulheres sob o 
modo de produção capitalista, que passavam a avocar um papel ativo social, política e economicamente. Ao considerarem o ingresso no trabalho social um caminho para a conquista de maior liberdade e autonomia das mulheres em relação ao poder patriarcal, Marx e Engels abriram caminho para a defesa da socialização das tarefas domésticas e do cuidado com as crianças.

Nesse sentido, o esforço empreendido por Engels em A origem da família, da propriedade e do Estado (de 1884) foi bastante significativo. A alegação de Engels de que a família individual moderna, baseada na "escravidão doméstica, transparente ou dissimulada, da mulher", representaria a "forma celular da sociedade civilizada", espelhando suas contradições e conflitos internos, lançou luz sobre o caráter multifacetado da opressão feminina e suas implicações sociais, políticas e econômicas. A dupla jornada feminina, ao mesmo tempo que submeteria as mulheres a árduas e incessantes tarefas, sob o jugo tanto do marido quanto do burguês, as aproximaria da luta geral de sua classe, possibilitando sua emancipação. Desse modo, a situação particular das mulheres passa a, necessariamente, integrar o projeto de transformação social mais abrangente. Essas já não são vistas como simples vítimas das relações sociais reproduzidas pela sociedade moderna, mas como protagonistas da mudança.

O paralelo traçado por Engels entre a condição enfrentada pelas mulheres e aquela experimentada pelos trabalhadores, que implicaria a convergência de suas lutas, foi igualmente apontado por Marx, em sua brochura Manuscritos econômico-filosóficos, ao relacionar a superação das relações de produção capitalistas à emancipação de toda a humanidade.

Da relação do trabalho estranhado com a propriedade privada depreende-se, além do mais, que a emancipação da sociedade da propriedade privada, da servidão, se manifesta na forma política da emancipação dos trabalhadores; não como se dissesse respeito somente à emancipação deles, mas porque, na sua emancipação, está encerrada a emancipação humana universal. Mas esta está aí encerrada porque a opressão humana inteira está envolvida na relação do trabalhador com a produção, e todas as relações de servidão são apenas modificações e consequências dessa relação (Marx, 2004b [1844], p. 88).

Uma vez que toda servidão humana está enredada na relação do trabalhador com a produção, e todos os tipos de servidão são somente modificações ou corolários dessa relação, pode-se deduzir que a emancipação feminina só seria efetivamente atingida através da luta contra o trabalho alienado, 
que reduz o ser humano, em suas funções, a um animal. A produção social apresenta-se, assim, simultaneamente, como reduto liberador das mulheres e aprisionador de suas potencialidades humanas. Somente a abolição das relações de produção capitalistas levaria ao fim da escravidão doméstica, da separação entre a esfera de reprodução - o lar (que converte o trabalho feminino em "serviço privado") - e a esfera de produção social, bem como da prostituição oficial e não oficial das mulheres. Nestes termos, o alcance da verdadeira igualdade entre os sexos pressuporia uma transformação radical da ordem social, pela socialização da propriedade privada. A derrota do capitalismo, portanto, significaria a derrota do patriarcado, posto que a base material da submissão da mulher ao homem seria minada.

A libertação da mulher exigiria, como primeira condição, a inclusão total do sexo feminino na indústria social, o que, por sua vez, requereria a supressão da família individual enquanto unidade econômica da sociedade. A indústria doméstica se converteria em indústria social e o tratamento e a educação das crianças passariam a ser uma questão pública. Para tanto, a sociedade cuidaria, com o mesmo empenho, de todos os filhos, quer fossem legítimos ou ilegítimos (Engels, 2000, p. 82).

Essa concepção foi exitosamente difundida por August Bebel, um dos principais líderes da social-democracia alemã, em seu livro Woman under socialism ( $A$ mulher sob o socialismo), de 1879, onde anuncia abertamente ser "um absurdo direcionar a mulher para a vida doméstica" (Bebel, 1923, p. 176) e prescreve a necessidade da completa igualdade de oportunidades entre homens e mulheres, de modo que estas passem a compartilhar da vida pública e das questões políticas e sociais, retirando-se do confinamento do lar. O fim da "escravização doméstica" só seria atingido na futura sociedade.

A vida social no futuro será cada vez mais pública. [...] A vida doméstica será restrita ao que é absolutamente necessário, enquanto será aberto um vasto campo para a satisfação dos instintos sociais. Espaços para reuniões, assembleias e discussões públicas sobre questões sociais, locais públicos para brincadeiras, leituras e refeições, bibliotecas, salas de concerto e teatros, museus e ginásios esportivos, parques, jardins, casas de banho, instituições educacionais de todo tipo, laboratórios etc.; tudo isso organizado e equipado da melhor forma possível oferecerá ricas oportunidades para todos os tipos de convívio e para o avanço da arte e da ciência (Bebel, 1923, p. 332; tradução da autora). 
A posição da mulher no organismo social como mãe e esposa ganharia novos contornos a partir de sua liberação em relação às tarefas domésticas, convertidas em serviços públicos prestados por profissionais de ambos os sexos. Assim, de acordo com Bebel, seriam instituídas creches, jardins de infância, escolas, cozinhas coletivas (com a utilização de princípios científicos na determinação da qualidade nutricional dos alimentos e da higiene na forma de preparo), lavanderias, serviços de limpeza, enfermarias e hospitais. A proteção social das crianças não excluiria a participação dos pais na educação dos filhos, sendo incentivada sua participação nas juntas escolares e nas demais instituições de ensino. Além disso, na medida em que a sociedade se responsabilizasse por propiciar todas as condições necessárias ao desenvolvimento mental, físico e psicológico das crianças - incluindo habitação, saúde, educação, arte, lazer -, pais e filhos gozariam de mais tempo livre para o convívio e estabelecimento de uma relação de afeto e respeito. A educação de crianças e adultos, preconizada por Bebel, deveria ser oferecida igualmente para homens e mulheres, de preferência em estabelecimentos mistos. Já que "ambos os sexos são plenamente qualificados para exercitar todos os direitos e deveres que a sociedade exige de seus membros adultos" (idem, ibidem, p. 329), desfrutando das mesmas oportunidades, todos seriam livres para seguir suas inclinações e desenvolver suas habilidades pessoais.

A mulher na futura sociedade é social e economicamente independente; ela não é mais submetida a nenhum vestígio de dominação e exploração; é livre, à semelhança do homem, senhora de seu destino. [...] Vivendo sob condições naturais, ela é capaz de desenvolver e exercitar suas faculdades e potencialidades mentais. Ela escolhe sua ocupação no campo que corresponder a seus desejos, inclinações e habilidades naturais, e trabalha em condições idênticas ao homem (Bebel, 1923, p. 343; tradução da autora).

Não obstante sua grande contribuição, a perspectiva histórica marxista guarda, ainda, reminiscências de seus primeiros escritos, particularmente no tocante à sua concepção acerca das origens da divisão social do trabalho, que teria como fundamento uma divisão sexual "natural" do trabalho, ditada pela procriação. Nesse sentido, a cisão entre as esferas pública e privada seria substituída por uma separação entre as esferas da produção e da reprodução, conforme esboçado no prefácio à primeira edição de As origens da família, da propriedade e do Estado, de 1884. 
Segundo a concepção materialista, o fator determinante, em última instância, na história, é a produção e a reprodução da vida imediata, que, no entanto, se apresentam sob duas formas. De um lado, a produção de meios de subsistência, de produtos alimentícios, habitação e instrumentos necessários para isso. De outro lado, a produção do mesmo homem, a reprodução da espécie. A ordem social em que vivem os homens de determinada época histórica e de determinado país está condicionada por esses dois tipos de produção: de um lado, pelo grau de desenvolvimento do trabalho e, de outro, pela família (Engels, 2000, p. 11-12).

Ao longo do século XX, a problemática da pretensa inserção das mulheres numa esfera reprodutiva apartada da produção gerou uma série de intervenções por parte de autoras feministas, dentro e fora do campo marxista. Infindáveis discussões procuraram levantar questionamentos acerca da relação da família e do trabalho doméstico com o processo produtivo.

É certo que a distinção entre os dois tipos de produção indispensáveis a toda ordem social, apontada por Engels no prefácio ao seu livro de 1884, isto é, a dimensão da produção dos meios de subsistência e necessidades sociais e a da produção dos próprios seres humanos, não foi objeto de maior elaboração por parte dos fundadores do materialismo histórico. Os escritos de Marx, particularmente $O$ capital, não visavam a uma teoria geral da reprodução, abordando a questão a partir da análise histórica das relações sociais desenvolvidas no âmbito do modo de produção capitalista. Contudo, deve-se atentar para o fato de que, de acordo com Marx, produção e reprodução (latu sensu) da ordem social são processos inter-relacionados, que não podem ser concebidos como momentos isolados. O processo de produção, portanto, é considerado "em sua permanente conexão e constante fluxo de sua renovação", de modo que todo processo social de produção é, ao mesmo tempo, um processo de reprodução (Marx, 1985, p. 153). Sob o capitalismo, tal continuidade exigiria o permanente consumo da força de trabalho pelo capitalista e a renovação das condições de exploração do trabalhador - que o obrigam a constantemente vender sua força de trabalho para viver (Marx, 1985, p. 153).

Na realidade, o trabalhador pertence ao capital antes que se venda ao capitalista. Sua servidão econômica é, ao mesmo tempo, mediada e escondida pela renovação periódica da venda de si mesmo, pela troca de seus patrões individuais e pela oscilação do preço de mercado do trabalho. O processo de produção capitalista, considerado 
como um todo articulado ou como processo de reprodução, produz, por conseguinte, não apenas a mercadoria, não apenas a mais-valia, mas produz e reproduz a própria relação capital, de um lado o capitalista, do outro o trabalhador assalariado (Marx, 1985, p. 161).

Como Marx destaca, se o processo de produção é iniciado com a compra da força de trabalho por determinado tempo, esse início deve se renovar incessantemente. $\mathrm{O}$ consumo da força de trabalho pelo capitalista como meio para a autovalorização do capital depende, assim, da constante manutenção e reprodução biológica e social da classe trabalhadora. Dessa maneira, a reprodução do capital encontra-se vinculada ao consumo individual de meios de subsistência realizado pelos trabalhadores, ainda que este se dê fora do ambiente da produção, por exemplo, na esfera familiar.

Embora esse consumo individual do trabalhador seja "para ele mesmo improdutivo, pois reproduz apenas o indivíduo necessitado, ele é produtivo para o capitalista e para o Estado, posto que gera a força produtora da riqueza alheia" (Marx, 1985, p. 158). Podemos concluir, portanto, que, segundo Marx, o consumo individual dos trabalhadores apresenta-se, em última instância, como condição objetiva do processo produtivo, sendo o combustível necessário para o dispêndio da força de trabalho. Tal como uma máquina necessita de permanente manutenção para o seu efetivo funcionamento, os trabalhadores, mesmo fora do processo direto de trabalho, tornam-se um acessório do capital e seu consumo individual, dentro de certos limites, "é apenas um momento do processo de reprodução do capital” (p. 158).

De acordo com Marx, portanto, apesar do consumo dos meios de subsistência não integrar o processo imediato de produção de mercadorias, constitui pressuposto da própria venda da capacidade de trabalho, sendo determinante para a absorção do maior quantum possível de trabalho vivo pelo capital. Assim, a produção de novas gerações de trabalhadores para a indústria capitalista exigiria não somente a sua manutenção física, como ainda a transmissão e a acumulação de habilidades. Nesse sentido, a família ainda se apresentaria como instituição fundamental, a despeito de cada vez mais os trabalhos complementares, agrícolas e domésticos - limitados à satisfação das necessidades familiares -, se transformarem em ramos de trabalho autônomos de tipo capitalista (Marx, 2004a, p. 96). 
Assim, o trabalho doméstico, geralmente atribuído à mulher, assumiria um papel significativo para a conservação e reprodução da capacidade de trabalho. Ao fornecerem meios de subsistência e assistência aos membros da família que ainda não trabalham, os trabalhos domésticos garantem as condições objetivas para a sobrevivência dos futuros trabalhadores. Do mesmo modo, o trabalho útil gratuito, produtor de valores de uso e fornecedor de serviços para a família, garante a preservação do esforço e do dispêndio de força vital para a sua utilização no processo de produção. Quanto menos os trabalhadores precisarem se ocupar com a sua própria manutenção - seja através do trabalho doméstico gratuito ou mesmo pela compra de bens e serviços no mercado -, maior o consumo produtivo de sua capacidade de trabalho por parte do capital.

Como o capitalista procura prolongar ao máximo possível a duração e intensidade do processo de trabalho - para além do tempo necessário para a reposição do salário -, a liberação do trabalho doméstico (como preparação de alimentos, limpeza da casa, lavagem e costura de roupas, fabricação e reparo de utensílios, cultivo de hortas, criação de animais, cuidados com crianças etc.) leva o trabalhador a expandir os limites de sua própria exploração. Ao mesmo tempo, o fornecimento gratuito de trabalho doméstico evitaria o efeito que o aumento dos custos de reprodução da força de trabalho produziria na média dos salários.

O reconhecimento da importância do consumo individual e da família para a continuidade do sistema produtivo, todavia, não conduz Marx a uma maior problematização acerca do trabalho doméstico. As causas da preservação da prerrogativa masculina de fruição gratuita do trabalho doméstico feminino e seu papel na conservação do valor de uso da força de trabalho para o processo de valorização, portanto, não são abordados de forma mais específica. A opressão feminina na esfera familiar, então, é percebida como parte dos resquícios de um modo produtivo decadente e de relações patriarcais anacrônicas, pois a exploração do trabalho das mulheres tenderia cada vez mais a estar concentrada em mãos capitalistas. Marx, assim, parece conceber que, com o desenvolvimento da produção capitalista, gradativamente as funções e atividades ainda não abarcadas pela relação de assalariamento - exercidas gratuitamente ou remuneradas de forma indireta - tenderiam a transformar-se em trabalhos assalariados. Consequentemente, o trabalho doméstico gratuito estaria em vias de extinção à medida que mais mulheres são envolvidas diretamente na produção, tendo sua força de trabalho 
consumida produtivamente. A satisfação das necessidades domésticas seria suprida, então, pela compra de tais serviços, fato que produziria efeitos nas relações entre os sexos e no poder da autoridade paterna/marital.

\section{O feminismo marxista e a ênfase sobre a opressão feminina no trabalho doméstico}

Não obstante sua subordinação à exploração capitalista em sua dimensão social, o trabalho doméstico e o cuidado com as crianças, mesmo quando remunerados, não são enquadrados por Marx no conceito de trabalho produtivo. Embora certos trabalhos improdutivos possam estar vinculados incidentalmente ao processo de produção - sendo possível, inclusive, que seu preço entre no preço da mercadoria (Marx, 2004a, p. 113) -, não se confundem com o trabalho produtivo, isto é, criador de valor de troca. Desse modo, a categorização como "produtivo" nada tem a ver com o conteúdo determinado do trabalho, com sua utilidade particular ou valor de uso resultante. Conforme dispõe Marx, "é produtivo o trabalhador que executa um trabalho produtivo, e é produtivo o trabalho que gera diretamente mais-valia" (Marx, 2004a, p. 109). Isto é, como o fim imediato e o produto por excelência da produção capitalista é a mais-valia, somente seria considerado produtivo o trabalho que fosse consumido diretamente no processo de produção, com vista à valorização do capital.

O mero desfrute do trabalho por outrem, portanto, não serviria para sua caracterização como "produtivo", sendo necessária a apropriação do trabalho não pago - sobretrabalho - como mais-valia, ou seja, que haja absorção "significativa” de trabalho vivo em prol da valorização do valor, da geração de valor de troca. Nestes termos, os "serviços" - isto é, os trabalhos destinados ao consumo como valores de uso, como é o caso dos trabalhos domésticos -, na medida em que não são utilizados como fatores vivos do capital no processo capitalista de produção (capital variável), não são considerados produtivos. Mesmo sendo consumidos pelo capitalista, este não o faz como representante do capital, mas de forma improdutiva, tal como ocorre com o consumo privado de mercadorias.

A caracterização do trabalho doméstico como improdutivo motivou uma série de críticas por parte de feministas contemporâneas, que atribuem a Marx uma visão misógina, que tende a menosprezar a importância da contribuição do trabalho doméstico feminino para a indústria social. Na tentativa 
de adequar a análise da peculiar situação das mulheres na esfera doméstica às categorias econômicas marxistas, inúmeros autores, principalmente a partir da década de 1960, produziram reflexões teóricas com o objetivo de evidenciar a importância da opressão feminina para o funcionamento e perenidade do sistema como um todo.

Margaret Benston, por exemplo, foi uma das primeiras autoras marxistas vinculadas à segunda onda do feminismo a destacar o trabalho realizado pelas mulheres fora do âmbito da produção de mercadorias como sendo a base econômica de sua opressão específica. Neste trabalho doméstico desvalorizado e imensurável, estariam as raízes materiais do status social secundário das mulheres. Assim, "numa sociedade em que o dinheiro determina o valor, as mulheres são um grupo que trabalha fora da economia monetária”, não sendo a atividade por elas realizada considerada um "verdadeiro trabalho" (Benston, 1997 [1969], p. 19; tradução da autora). Embora realizem um trabalho social e historicamente necessário para a acumulação capitalista, sendo responsáveis pela produção de valores de uso em atividades associadas ao lar e à família, as mulheres participariam do trabalho assalariado produtivo apenas de forma transitória e excepcional, como um exército industrial de reserva conveniente e elástico. A relação das mulheres, enquanto grupo, com os meios de produção seria, portanto, análoga à da produção pré-industrial desenvolvida por servos e camponeses. Cada família constituiria uma unidade de produção, uma entidade pré-mercantil, que desempenharia uma função estabilizadora na sociedade capitalista.

De modo aproximado, Mariarosa Dalla Costa e Selma James (1997, p. 49) também conferiram maior relevância ao papel social da instituição familiar, apresentando-a como "o pilar da organização capitalista do trabalho". Longe de ser considerada um mero reflexo da esfera produtiva, a família nuclear seria indispensável para o desenvolvimento da produção capitalista, já que, como "fábrica social", ela se tornaria um centro de condicionamento, consumo e reserva de trabalho. Conforme nos explica James, "a comunidade não é uma arena de liberdade e lazer auxiliar à fábrica, em que, por coincidência, se encontram mulheres que são degradadas como serventes pessoais dos homens. A comunidade é a outra metade da organização capitalista, a outra área oculta de exploração capitalista, a outra fonte escondida de trabalho excedente" (Costa e James, 1997, p. 34). 
O capital, portanto, teria moldado a família para atender às suas necessidades, desatrelando o homem dos trabalhos realizados na esfera doméstica a fim de liberá-lo para a venda de sua força de trabalho. Ao mesmo tempo, essa fratura na família intensificaria o isolamento e a opressão de seus membros não assalariados - mulheres e crianças -, que perderiam seu relativo poder e status ao serem excluídos da produção de mercadorias, passando a depender do salário do trabalhador adulto masculino para sua subsistência. Dessa forma, a dependência das mulheres seria concebida a partir de um ponto de vista equivocado - ancorado no "mito da incapacidade feminina" -, qual seja, o de que o trabalho empreendido pelas mulheres se resumiria à realização de serviços e à produção de valores de uso que em nada contribuiriam para a produção da mais-valia. Logo, como o capital as excluiu do processo imediato de produção social organizada, seu papel no ciclo de produção social permaneceria invisível e somente o produto de seu trabalho - o trabalhador - seria aparente. A dominação do capital, portanto, atingiria indelevelmente as mulheres, transformando seus órgãos vitais e reprodutivos em instrumentos para a acumulação de trabalho excedente, uma vez que define como seu trabalho primordial a reprodução da força de trabalho.

De acordo com Costa e James, o obscurecimento da exploração do trabalho doméstico feminino seria, inclusive, encampado por parte do movimento socialista, que não reconheceria o fato de que a exploração do trabalho não assalariado seria organizada justamente por meio do sistema de assalariamento. Presa em condições de trabalho pré-capitalistas, submetida ao controle coercitivo e à chantagem afetiva de seus familiares, a mulher encontrar-se-ia então na posição de "escrava de um escravo assalariado", de modo que sua escravidão asseguraria a escravidão de seu marido (Costa e James, 1997, p. 50). Ao não se ver obrigado a pagar pelas horas de trabalho despendidas pelas mulheres dentro de casa, a figura do patrão ficaria camuflada por detrás da do marido, que assim aparenta ser o único a usufruir do trabalho doméstico. Destarte, para as autoras, não basta a renúncia aos trabalhos domésticos e a participação no trabalho social para que se atinja a liberação plena das mulheres. A rejeição do papel social de dona de casa e a superação do isolamento doméstico seriam apenas elementos da luta geral anticapitalista a ser levada adiante pelas mulheres. A ideia da "liberação pelo trabalho" é substituída pela luta contra a dupla escravidão e pela destruição da família nuclear, tal como foi estabelecida pela ordem social capitalista. 
Caberia às mulheres, portanto, saírem de casa e se unirem a outras mulheres, participando ativamente de reuniões de fábrica, assembleias de bairro, encontros de estudantes e quaisquer espaços em que possam expor as contradições e frustrações impostas pelo capital sobre a família.

Fora do "gueto doméstico" e da "clausura da família", as mulheres são capazes de descobrir novas identidades e exercer o seu poder como protagonistas da luta, desfrutando de vastas experiências de organização e planejamento da luta coletiva. A revolta social, pois, seria a fonte básica de educação e capacitação das mulheres, que, juntamente com suas próprias formas de rebelião, adeririam também às tradicionais organizações de classe. Sendo assim, mesmo constituindo uma "casta" própria, caracterizada pelas relações sociais derivadas da exploração de seu trabalho doméstico, as mulheres donas de casa não poderiam ser consideradas como exteriores à classe trabalhadora.

Seguindo um caminho diferente, de crítica às explicações estritamente econômicas e funcionalistas - que procuram enfatizar a relevância do trabalho doméstico na produção de mais-valia -, algumas feministas marxistas concentraram-se no repúdio da categorização do trabalho doméstico como produtivo e na ênfase ao aspecto ideológico relacionado à opressão feminina e à posição subordinada das mulheres sob o capitalismo.

Maxine Molyneux, por exemplo, afirma que reconhecer a importância social do trabalho doméstico não implica igualá-lo ou inseri-lo na lógica da produção social capitalista. Embora a autora não conteste que a subordinação feminina funda-se em uma base material, vinculada à economia política, adverte que "qualquer que seja a relação entre a esfera doméstica e as exigências da reprodução social, ela não se estabelece simplesmente pela sua funcionalidade para o capitalismo" (Molyneux, 1979, p. 20; tradução da autora). Assim, em vez de pressupor o trabalho doméstico como sendo crucial ao capitalismo, de forma que sua abolição acarretaria a queda do próprio sistema, as análises teóricas sobre o trabalho doméstico deveriam considerar as suas profundas transformações, resultantes da expansão do capitalismo e da luta de classes, capazes de gerar efeitos contraditórios para o capital.

Segundo Molyneux, o reducionismo econômico e os argumentos funcionalistas obliterariam a especificidade cultural e histórica do trabalho doméstico. A seu ver, o trabalho útil, "concreto", na esfera doméstica e o trabalho abstrato, vinculado à produção de valor, portanto, não seriam trabalhos 
comparáveis, de modo que não haveria base para o cálculo da transferência do tempo de trabalho excedente entre as duas esferas - a não ser que a lei do valor fosse redefinida. Nestes termos, para Molyneux, "uma coisa é produzir uma análise marxista do trabalho doméstico", e outra coisa bem diferente seria tentar incluir o trabalho doméstico no conceito de modo de produção capitalista e nas leis de movimento da economia capitalista (idem, ibidem).

O destaque conferido às formas psicológicas e à dimensão ideológica da dominação masculina, internalizada e institucionalizada, também foi um caminho trilhado por autores que procuravam se distanciar do viés econômico. Mesmo repudiando o idealismo feminista, que concebe a opressão patriarcal como fenômeno universal e a-histórico, inúmeros teóricos buscaram conciliar a análise de fatores geralmente concebidos como superestruturais com a perspectiva materialista. A síntese das contribuições de Marx, Althusser e Freud, desenvolvida por Juliet Mitchell, procurou mover-se nessa mesma direção. Segundo a autora, a família assume um papel de socialização e reprodução das relações sociais hierarquizadas, cuidando para que as crianças aprendam a se autodisciplinar, a fim de trabalharem de maneira eficiente, sem a necessidade de uma supervisão constante. Com efeito, o espaço reprodutivo é visto como uma espécie de imitação "caricata" do mundo produtivo, no qual os filhos são encarados como "produtos". Assim, a procriação se transformaria em uma espécie de substituto do trabalho, isto é, "uma atividade na qual o filho é visto como um objeto criado por sua mãe, do mesmo modo que uma mercadoria é criada por um operário" (Mitchell, 1977, p. 199; tradução da autora).

A manutenção da mulher em casa e o lugar subalterno que ela ocupa nas sociedades de classe, por meio da injunção das regras da família patriarcal, garantiriam a produção de valores de uso necessários à reprodução biológica da força de trabalho e à conservação de um reservatório inesgotável de força de trabalho disponível. Contudo, segundo a autora, a posição das mulheres na esfera econômica, por si só, não seria suficiente para explicar a construção social das diferenças sexuais e seus componentes psíquicos - para o que somente a psicanálise poderia fornecer a chave teórica. A condição feminina, destarte, deveria ser compreendida a partir da análise das estruturas específicas e sobredeterminadas, que, juntas, formam uma unidade complexa.

Assim, conforme assinala Mitchell, a produção, a reprodução, o sexo e a socialização das crianças seriam estruturas autônomas e independentes - em- 
bora, em última instância, determinadas economicamente -, que comporiam uma "totalidade complexa". A combinação histórica e a inter-relação entre as várias estruturas dariam origem a uma "unidade complexa" da posição feminina, sendo necessário examiná-las separadamente e em profundidade para se entender qual é a presente unidade e como mudá-la (Mitchell, 1966, p. 17). Por esse prisma, o "modo de reprodução" não variaria necessariamente de acordo com o "modo de produção", podendo inclusive continuar efetivamente o mesmo em face às alterações dos diferentes modos de produção. A revolução socialista, portanto, não ocasionaria inevitavelmente uma transformação nas relações de reprodução e no convívio entre os sexos, uma vez que a liberação das mulheres só poderia ser conquistada se todas as quatro estruturas em que estão integradas fossem transformadas. Para tanto, seria preciso atacar o elo mais fraco da combinação, isto é, as estruturas que sejam mais facilmente modificáveis, de modo a desencadear uma ruptura conexa ("unité de rupture"), que transforme todas as estruturas (Mitchell, 1966, p. 30). Nesse sentido, a luta por reformas seria concebida como parte da luta revolucionária pela liberdade e pelo socialismo.

As reivindicações femininas sempre foram apresentadas como reformas. [...] As posições de esquerda que afirmam indubitavelmente que elas o são, não somente mimetizam a atitude da sociedade burguesa, mas também subestimam seriamente $o$ papel do reformismo na política revolucionária. Apenas quando uma teoria e estratégia revolucionárias da opressão feminina que desafiem os governos "democráticos" forem desenvolvidas, nós poderemos decidir quais questões são reformas e subordiná-las à luta pela liberdade e pelo socialismo. Na ausência dessa estratégia, essas "reformas" podem se tornar a primeira stepping-stone (Mitchell, 1971, p. 73; tradução da autora).

Embora Juliet Mitchell tenha sido muito criticada por encarar produção, reprodução, sexo e socialização como realidades autônomas com dinâmicas próprias, também proporcionou uma renovação dentro da teoria feminista-socialista no tocante às análises sobre as relações entre a ideologia de gênero e a condição econômica das mulheres na sociedade capitalista. Michelle Barrett (1982), por exemplo, considerou sua defesa da validade da psicanálise como a chave para a compreensão de como a feminilidade e a masculinidade são construídas. Para ela, a ideologia sexista não deve ser concebida como reflexo das condições materiais de poder e domínio masculinos, nem tampouco como uma manipulação da realidade que serve aos 
interesses dos homens. Assim, resumir a ideologia à "falsa consciência", a uma derivação de contradições econômicas ao nível mental, seria resvalar para uma concepção mecânica.

Segundo Barrett (1997 [1980], p. 89; tradução da autora), "está claro que uma concepção do capitalismo em que todas as formas de ideologia são percebidas como um reflexo da exploração capitalista do trabalho pelo capital, em que o gênero não toma parte, terá pouca utilidade para uma análise feminista”. Barrett desenvolve então uma crítica tanto à noção de que a ideologia seria tão material quanto as relações econômicas, como à perspectiva de que a economia e a ideologia estão relacionadas em um único sistema de determinação. Nesse sentido, propõe a revisão da teoria de Louis Althusser, aliando-a a uma teoria do discurso que leve em conta os efeitos materiais da ideologia de gênero e as condições históricas de produção e reprodução da vida material. Desse modo, ainda que Barrett restrinja a definição do conceito de ideologia a fenômenos mentais - isto é, a processos relacionados à consciência, motivação, emoção e categorias de significação - ela procura relacioná-la às práticas históricas e contextos sociais específicos em que se apresenta.

Ideologia é o termo genérico para os processos pelos quais o significado é produzido, desafiado, reproduzido, transformado. Como o significado é negociado primordialmente através dos meios de comunicação e significação, é possível sugerir que a produção cultural proporciona um importante lugar para a construção de processos ideológicos. [...] A ideologia está embutida historicamente na prática material, mas isto não significa que ela seja teoricamente indistinguível das práticas materiais ou que tenha uma relação direta com elas (Barrett, 1997, p. 93; tradução da autora).

O processo ideológico vinculado a uma particular formação social, portanto, possui conexão com as relações de produção, sem, no entanto, ser inexoravelmente determinado por elas. A ideologia de gênero não seria um requisito essencial para o funcionamento do capitalismo, mas poderia desempenhar um papel importante para a construção histórica da divisão de trabalho capitalista e a reprodução da força de trabalho. Assim, as ideologias que acompanham a divisão sexual do trabalho e o significado atribuído aos trabalhos de homens e mulheres podem concorrer para a manutenção do sistema, de forma que: 
A crença de que um homem (branco) tem o "direito" a trabalhar sobre e acima dos direitos das mulheres casadas ou imigrantes tem tido efeitos significativos na organização da força de trabalho. Essa crença tem que ser, então, levada em consideração quando se analisar a divisão do trabalho, mas seu lugar nas práticas materiais não a torna material (Barrett, 1997, p. 91; tradução da autora).

Se a ideologia de gênero desempenha um papel significativo nas relações de produção - através da socialização pelo gênero, do sistema educacional, da fundamentação da participação intermitente e suplementar feminina no trabalho, das definições de competências e habilidades, da destinação feminina ao trabalho doméstico e à maternidade -, para a autora, contudo, a relação de assalariamento e a contradição entre trabalho e capital seriam "sex-blind" (cegos ao sexo) e operariam independentemente do gênero. Diferentemente de autoras como Johanna Brenner e Maria Ramas (1984), que apresentam a divisão sexual do trabalho como sendo decorrente dos papéis assumidos na reprodução biológica, reservando às mulheres as funções de lactação, gestação, procriação e cuidado com crianças, Barrett considera a divisão sexual do trabalho e a ideologia de gênero como vestígios pré-capitalistas, apropriados e moldados pelas formações sociais capitalistas, podendo, assim, ser contestados no plano das representações (Barrett, 1984).

Embora as análises que se debruçam sobre as formas ideológicas e os aspectos não econômicos vinculados à opressão feminina tenham contribuído para a compreensão da sobrevivência de ideias e concepções pré-capitalistas sobre a identidade e papéis sexuais de homens e mulheres que contradizem o modelo universalista do homoeconomicus, tal perspectiva apresenta um sério risco de resvalar para uma concepção idealista e a-histórica, que atribui à esfera ideológica uma autonomia e dinâmica próprias, apartadas da realidade material. Como Marx já havia alertado, considerar a moralidade, a religião, a metafísica e as demais formas da consciência como realidades próprias, fundantes do ser social, é elevar a vida social a mero reflexo ou determinação das consciências individuais. $\mathrm{O}$ debate entre feministas marxistas a respeito da relação entre a ideologia de gênero e as bases materiais com frequência centrou-se em concepções que ora dissociavam as representações sociais das relações engendradas no âmbito produtivo, ora recaíam na dualidade e separação entre as esferas produtiva e reprodutiva. A totalidade sistêmica é concebida, assim, no plano da abstração e não em termos históricos. 
Se autores e autoras taxados de "economicistas" ou "reducionistas" falharam em detectar o sistema de valores e papéis que contribui para reproduzir o modo de produção como um todo, realizaram por outro lado um válido esforço intelectual para inserir a complexa subordinação feminina na lógica de acumulação capitalista. Graças a essa perspectiva, fenômenos vinculados à vida familiar tiveram seu aspecto econômico desnudado. Dessa maneira, tornaram visível o controle da mão de obra feminina e infantil através da instituição familiar - que permite ao capitalismo regular a participação feminina no mundo do trabalho produtivo e expandir ou reduzir a dimensão do exército de reserva constituído por uma força de trabalho sub-remunerada. Ao mesmo tempo, permitiu atentar para a relação entre a suposta "vocação materna natural da mulher", que resulta em sua responsabilização pelas atividades domésticas, e a divisão sexual do trabalho nos espaços produtivos.

Como nos mostram Helena Hirata e Philippe Zarifian (2009), considerar o trabalho doméstico como o oposto da objetificação, ou como "forma privilegiada de expressão do amor", baseado na "disponibilidade materna e conjugal" e em relações afetivas, é não somente desconsiderar os gestos repetitivos e os atos cotidianos estafantes de manutenção do lar e da educação dos filhos, que são atribuídos exclusivamente às mulheres, como a própria dimensão sexuada do trabalho produtivo. Sob esse ponto de vista, a entrada das mulheres no mercado de trabalho deve ser compreendida abarcando sua permanente conexão com o trabalho doméstico, pois "para as mulheres, os limites temporais se dobram e multiplicam entre trabalho doméstico e profissional; opressão e exploração se acumulam e articulam, e por isso elas estão em situação de questionar a separação entre as esferas da vida - privada, assalariada, política - que regem oficialmente a sociedade moderna" (Hirata e Zarifian, 2009, p. 254). Sendo assim, podemos concluir, juntamente com os autores, que trabalho profissional e trabalho doméstico, produção e reprodução, assalariamento e família, classes social e sexo social são categorias indissociáveis.

O trabalho reservado às mulheres na esfera produtiva, bem como a sua precarização e baixa remuneração, reflete sua posição na hierarquia de gênero existente tanto na família quanto no mundo do trabalho. Nesse sentido, produção e reprodução condicionam-se reciprocamente, alimentando um padrão de divisão do trabalho que garante a reprodução de todo o sistema social. Essa divisão sexual do trabalho contribui, igualmente, para genera- 
lizar e acentuar o processo de precarização do trabalho, que se torna cada vez mais "feminino" em sua caracterização - isto é, com a predominância de ocupações subordinadas que exigem baixa qualificação, pagam baixos salários e são realizadas em jornadas parciais.

A opressão da mulher constitui, portanto, inegavelmente, um dos pilares de sustentação da sociedade burguesa, o que, todavia, não significa que sua condição de opressão possa ser efetivamente compreendida fora do marco de classe. Embora mulheres oriundas de diferentes classes possam sofrer os efeitos do status inferior atribuído ao sexo feminino, sua própria posição subalterna está associada à divisão sexual do trabalho estruturada na sociedade. Sendo assim, como destaca Cecília Toledo, entre a condição de opressão e o capitalismo existe um vínculo indissolúvel:

A opressão, atitude de se aproveitar das diferenças que existem entre os seres humanos para colocar uns em desvantagem em relação aos outros, gera uma situação de desigualdade de direitos, de discriminação social, cultural e econômica. A existência de setores oprimidos e marginalizados não é fruto do acaso. É o resultado de um sistema que se assenta na desigualdade e na divisão; numa sociedade dividida em classes e num sistema econômico assentado sobre a exploração, a pilhagem e a submissão de milhões e milhões de seres humanos (Toledo, 2005, p. 16).

Dessa forma, a opressão cultural e social das mulheres é combinada à sua exploração econômica, reforçando-se mutuamente. Conforme Toledo, as desigualdades de gênero são alimentadas e aprofundadas a cada dia, de inúmeras formas, para que continuem a servir ao modo de produção dominante. O trabalho doméstico, por exemplo, seria responsável por agravar o processo de alienação vivenciado pela mulher no mercado de trabalho e no conjunto das relações sociais. Além de embrutecê-la, porque lhe toma o tempo necessário ao aprimoramento intelectual e artístico, à participação política e social, separa-a da produção material do conjunto da sociedade ou reserva-lhe um lugar subalterno:

Seu trabalho é o trabalho alienado em si mesmo, já que nem mercadorias produz. Seu resultado não é concretizado em coisas palpáveis que possam se contrapor à mulher enquanto trabalhadora doméstica. Ela se anula em objetos não visíveis. É trabalho que se esvai em trabalho. Se a alienação vem com a separação do homem do produto de seu trabalho, um trabalho que não gera produto (como é o caso do 
trabalho doméstico) só gera trabalho, é um trabalho contínuo, sem fim. [...] Ela trabalha para que ele produza mercadorias, ou seja, para que o trabalho de outrem se fixe no objeto. [...] O trabalho da mulher em casa, então, não se objetiva em nada, portanto, nem mesmo se realizaria efetivamente enquanto trabalho. [...] o trabalho da mulher só pode se efetivar no trabalho do homem, no produto que ele cria; por isso ela é duplamente alienada (Toledo, 2005, p. 54).

Se a dupla alienação a que a mulher é submetida constitui um fator importante para a estabilidade do sistema, não é cabível, no entanto, concluir que a sociedade burguesa é incapaz de reproduzir-se sem a estrutura familiar patriarcal. A apropriação, pelos proprietários dos meios de produção, do valor produzido pela força de trabalho excedente não depende diretamente de essa força de trabalho ser reproduzida e mantida no interior de uma organização privada - a família. Indivíduos isolados, providos ou não de auxílios por parte do Estado, continuam à mercê da venda de sua força de trabalho para garantir sua sobrevivência. Historicamente, contudo, a organização familiar ainda permanece regra nas diferentes sociedades industriais, desempenhando um papel ideológico importante, organizando o controle da sexualidade e da capacidade reprodutiva da mulher e moldando a educação das futuras gerações de trabalhadores.

A família como "refúgio", então, não passa de uma representação ideológica que contribui para que as suas contradições internas sejam obscurecidas ou aparentem ter vida própria, dissociada das relações de produção. Por conseguinte, em concordância com a afirmação de Frigga Haug (2006, p. 322), "podemos assumir que o desenvolvimento das forças produtivas, do progresso, e da acumulação de riquezas se relaciona com a esfera da produção dos meios de vida, que, portanto, parece ter prioridade, subordina a esfera de vida como uma pressuposição e um resultado”. Devemos considerar, assim, as diferentes maneiras pelas quais o desenvolvimento das forças produtivas se introduz na produção da vida em si mesma, seja na reprodução da vida como forma de mercadoria, seja pela utilização do corpo da mulher como matéria-prima para a produção, ou ainda pela subordinação da moral às exigências das relações de produção em seu modo capitalista de orientação utilitária.

Seguindo o argumento de Haug, é importante considerarmos as relações de gênero como relações de produção, reconhecendo o emprego de relações de gênero no nível do conjunto total como um fundamento de acumulação 
capitalista, isto é, entendendo a função da divisão do trabalho entre o lar e a indústria e, com isso, o papel das relações de gênero na reprodução da sociedade capitalista. Nesse sentido, o gênero se converte em uma categoria que ajuda a reproduzir o conjunto das relações sociais, não sendo mais uma questão acessória, estritamente privada.

Sustento que todas as práticas na sociedade estão determinadas por relações de gênero - têm um subtexto de gênero -, sendo, por isso, colocadas em chave de dominação e que, portanto, devemos incluí-las em qualquer análise e compreensão da sociedade. Isso se fundamenta em uma produção social dupla, na medida em que produz a vida e os meios de vida. Já sabemos que a produção da vida se refere à própria vida como também à procriação; chamamos essas duas produções de "reprodução", embora este seja um conceito errôneo já que a produção dos meios de vida deve também ser reproduzida, na forma de capital, matérias-primas, força de trabalho etc. Por conseguinte, a diferença não é entre produção e reprodução, mas sim entre vida e meios de vida, e preferiria falar não de reprodução, mas sim de sustento de vida (subsistência) e desenvolvimento de atividades vitais (Haug, 2006, p. 321).

Como a autora aduz, produção e reprodução são inseparáveis, compondo a totalidade da organização da produção dos meios de vida. Por conseguinte, um determinado modo de produção leva sempre aparelhado um determinado modo de cooperação, que abarca a soma das forças produtivas acessíveis ao homem e condiciona o estado social. A específica divisão social e doméstica do trabalho compõe o complexo de relações sociais inscrito em um modo de produção em dado momento histórico, determinando igualmente um padrão de dominação nas relações de gênero. Logo, pensar em relações de gênero como relações de produção implica considerar a multiplicidade de práticas que concorrem para a reprodução do conjunto social.

Se a cooperação dos assalariados na produção imediata é um efeito do capital, de modo que "a conexão de suas funções e sua unidade como corpo total produtivo situa-se fora deles, no capital, que os reúne e os mantém unidos" (Marx, 1985, p. 263), não se pode perder de vista a complementaridade e a conexão desses trabalhos com aqueles não subordinados diretamente à autoridade capitalista. Embora não caiba a dilatação do conceito de trabalho produtivo, no sentido de abarcar trabalhos não produtores de mais-valia, sob o risco de se comprometer o entendimento do processo de acumulação capitalista, também não é adequado encarar o trabalho coletivo como suficiente para a reprodução 
do modo de produção. Estando as esferas não produtivas atreladas à produção capitalista, vista em sua totalidade, podemos inferir, então, em consonância com as análises marxistas, que as atividades voltadas para a manutenção dos trabalhadores podem ser concebidas como sendo igualmente indispensáveis para a reprodução do sistema como um todo. Conforme Marx esclarece, sob o modo de produção capitalista, produção e reprodução apresentam-se como partes do mesmo processo global de valorização:

Se a produção tem forma capitalista, então a terá a reprodução. Como no modo de produção capitalista o processo de trabalho só aparece como um meio para o processo de valorização, assim a reprodução aparece apenas como um meio para reproduzir o valor adiantado como capital, isto é, como valor que se valoriza (Marx, 1985, p. 153).

Desse modo, a participação feminina na indústria social, ainda que indiretamente através do trabalho doméstico, não pode ser concebida isoladamente. Por essa razão, mesmo que não componham o corpo de trabalho social que atua no processo produtivo - que depende da articulação de muitos processos de trabalho individuais, dispersos e independentes entre si, formando um processo de trabalho social combinado -, as mulheres que desempenham trabalhos domésticos fazem parte do exército proletário, na medida em que participam do trabalho global, tendo sua força de trabalho simultaneamente explorada. Assim como Frigga Haug (2006, p. 317) depreende, “o entrelaçado da exploração capitalista e uma específica divisão do trabalho em relações de gênero históricas mostram que, entre outros tipos de opressão, a produção capitalista se apoia na opressão da mulher".

Com base nessa argumentação, podemos concluir ainda que as mulheres (e homens) que desempenham atividades reprodutivas não se encontram descoladas da "experiência de classe", muito embora estejam submetidas a formas brutais de alienação. Mesmo quando alijadas do processo de produção, constituindo uma força auxiliar na reprodução do capital, encontram-se subordinadas a ele, compartilhando da sorte dos membros assalariados da família. Isto também se aplica às mulheres que compõem a família burguesa: ainda que não possuam propriedade e se encontrem em uma posição subordinada dentro do lar, sua vivência as aproxima da classe capitalista, partilhando do interesse na continuidade da exploração da força de trabalho da classe trabalhadora. 
Porém, convém mencionar, seu pertencimento à classe burguesa não implica, necessariamente, seu ingresso na luta de classes como opositoras das classes trabalhadoras, pois, como Marx e Engels elucidam no Manifesto do Partido Comunista, diante da intensificação da luta de classes, uma fração da classe dominante - "especialmente a parte dos ideólogos burgueses que chegaram à compreensão teórica do movimento histórico em seu conjunto" - se desliga desta, ligando-se à classe revolucionária (Marx e Engels, 2005, p. 49). Dessa forma, a opressão feminina e o controle sobre sua força de trabalho e sua capacidade reprodutiva por parte dos homens de sua própria classe podem conduzir à percepção das contradições sistêmicas e ao desenvolvimento de uma empatia e solidariedade em relação às demais formas de opressão e exploração existentes na sociedade.

Finalmente, como pretendemos mostrar, a dimensão reprodutiva não pode ser devidamente compreendida apartada da produção social, uma vez que é sua premissa e condição fundamental. A família, por conseguinte, não é uma instituição autônoma e independente, não cabendo a separação tradicional no pensamento moderno entre as esferas pública e privada. Devemos considerar o fato de que a apropriação privada do trabalho doméstico e os papéis e estereótipos atribuídos às mulheres contribuem para estruturar o modo de produção através da permanência de configurações de divisão sexual do trabalho dentro e fora da indústria. Como aduz Clara Araújo (2000, p. 67), a exploração de classe articula-se com a opressão de gênero, ainda que os processos de trabalho ganhem uma aparência naturalizada, tornando-se gradativamente elementos "coisificados" e exteriores aos indivíduos que deles compartilham.

Sendo assim, a dominação patriarcal e a dominação capitalista constituem duas faces de um mesmo modo de produzir e reproduzir a vida, colaborando para a manutenção de determinada ordem social. Conquanto a dominação feminina seja anterior ao advento do capitalismo, este tende a captar e acentuar as contradições existentes em qualquer sociedade baseada na propriedade privada, em proveito da acumulação capitalista - sejam elas baseadas em distinções de sexo, raça, etnia, religião, nacionalidade ou qualquer outro critério.

\section{Considerações finais}

Nas fileiras marxistas, portanto, as discussões levantadas pelos defensores dos direitos das mulheres procuraram desnaturalizar o papel ocupado pelas 
mulheres na divisão social de trabalho, questionando sua exclusão da esfera pública e seu confinamento no lar. As feministas revolucionárias, munidas do arcabouço teórico marxista, puderam diferenciar-se dos demais grupos feministas de vertente liberal que propunham reformas moderadas, visando atender, em geral, aos anseios das mulheres oriundas das classes privilegiadas por acesso à escolaridade e maior independência econômica.

Até o início do século XX, no entanto, as tarefas domésticas, concebidas como atividade gratuita e improdutiva, não eram inseridas no conceito de "trabalho" pelos próprios adeptos da social-democracia, de modo que suas realizadoras não assumiam a identidade de "trabalhadoras" senão por intermédio de seus pais ou maridos, não importando o tempo gasto na execução desses afazeres. Argumentava-se que, enquanto permanecessem no lar e não ingressassem no mercado de trabalho, as mulheres "donas de casa" continuariam a vivenciar uma condição de dependência material e psicológica, estando alheias às discussões políticas.

Nesse sentido, o esforço empreendido nos primeiros anos da Revolução Russa, visando à liberação das mulheres do trabalho doméstico e sua inclusão na indústria social - através da criação de lavanderias, creches e restaurantes coletivos - possuía uma significação tanto econômica como política, uma vez que asseguraria maior apoio ao processo revolucionário. Tal projeto, no entanto, teria esbarrado não apenas na incapacidade econômica do Estado de fornecer tais serviços, mas na sobrevivência de valores patriarcais tradicionais e práticas antifeministas nos círculos operários, burocráticos e camponeses. Como nos mostra a historiadora norte-americana Wendy Goldman (2014), a divisão sexual do trabalho dentro e fora da família foi ainda reforçada no período estalinista, quando a política repressora do governo silenciou militantes e intelectuais progressistas, revogou direitos, cerceou a participação política feminina e passou a difundir propagandas de glorificação da instituição familiar e de exaltação da maternidade.

Embora críticas feministas contemporâneas, como Andrea Nye (1995, p. 74), considerem que a teoria marxista teria relegado a questão das mulheres à "periferia", estando presa a um "economicismo estreito" - de modo que não ofereceria instrumentos teóricos para a compreensão do papel secundário das mulheres na família, sua exploração nos meios de comunicação de massa, seu constrangimento sexual e vitimização -, a análise da produção intelectual e da prática das feministas marxistas revela a importância das 
contribuições do materialismo histórico para a formulação de uma crítica radical ao sistema capitalista que conduza à emancipação feminina. Nesse aspecto, concordamos com Lise Vogel (1981), que considera residir a origem de grande parte das críticas direcionadas ao marxismo, justamente, na apropriação e vulgarização de uma vertente específica da teoria marxista de caráter determinista, que contribuiria para ocultar a potencialidade do marxismo para a compreensão da questão da opressão das mulheres.

A perspectiva feminista marxista, portanto, ao localizar a opressão das mulheres através do trabalho doméstico no centro da dinâmica capitalista, foi responsável por reavivar a discussão teórica sobre a conciliação da luta revolucionária com as demandas, iniciativas e estratégias dos movimentos pelos direitos das mulheres, além de refletir sobre a postura machista e excludente presente em partidos e sindicatos. Do mesmo modo, abriu caminho para o questionamento da origem e permanência da divisão sexual do trabalho, seja no lar ou no mercado, não obstante sua "incrível plasticidade" (Hirata e Kergoat, 2007, p. 601).

Estudos recentes que denunciam a continuidade da exploração do trabalho doméstico feminino nos séculos XX e XXI demonstram como a desigualdade e hierarquia são ainda utilizadas em benefício da reprodução do sistema capitalista (Nogueira, 2006). Dessa maneira, embora ocorra uma reconfiguração das relações entre os sexos, com o crescente ingresso de mulheres no mercado de trabalho e seu maior acesso à educação e às posições de poder - sobretudo nos países desenvolvidos ou em desenvolvimento, em que há a delegação do trabalho reprodutivo a outras mulheres que assumem o papel de babás, faxineiras, cozinheiras e cuidadoras -, a grande maioria das mulheres continua a ser submetida a trabalhos precários e sub-remunerados, além de acumular tarefas domésticas estafantes sem reconhecimento social.

\section{Bibliografia}

ARAÚJO, Clara (2000). "Marxismo, feminismo e o enfoque de gênero". Crítica Marxista, n. 11, p. 65-70.

BARRETT, Michelle (1982). "Narcisism and the family: a critique of Lasch". New Left Review, n. 135, pp. 35-48.

(1984). "Rethinking women's oppression: a reply to Brenner and Ramas”. New Left Review, n. 146, pp. 123-128. 
(1997 [1980]). "Ideology and the cultural production of gender", em HENNESSY, R. \& INGRAHAM, C. (eds.). Materialism feminism: a reader in class, difference, and women's lives. New York: Routledge.

BEBEL, August (1923 [1879]). Woman under socialism. New York: NY Press. BENSTON, Margaret (1997 [1969]). “The political economy of women's liberation”, em HENNESSY, R. \& INGRAHAM, C. (eds.). Materialism feminism: a reader in class, difference, and women's lives. New York: Routledge.

BRENNER, Johanna \& RAMAS, Maria (1984). "Rethinking women's oppression today”. New Left Review, n. 144, pp. 33-71.

COSTA, Mariarosa Dalla \& JAMES, Selma (1997). "Women and the subversion of the community” (1972), em HENNESSY, R. \& INGRAHAM, C. Materialist feminism: a reader in class, difference, and women's lives. New York: Routledge.

ENGELS, Friedrich (2000 [1884]). A origem da família, da propriedade e do Estado. São Paulo: Escala.

(2008 [1844]). A situação da classe trabalhadora na Inglaterra. São Paulo: Boitempo.

GAY, Peter (2001). A experiência burguesa, da rainha Vitória a Freud: o cultivo do ódio. São Paulo: Companhia das Letras.

GOLDMAN, Wendy (2014). Mulher, Estado e revolução: política familiar e vida social soviéticas, 1917-1936. São Paulo: Boitempo.

HAUG, Frigga (2006). "Para uma teoria das relações de gênero", em BORON, A. A.; AMADEO, J. \& GONZÁLEZ, S. (orgs.). A teoria marxista hoje: problemas e perspectivas. Buenos Aires: CLACSO (Consejo Latinoamericano de Ciencias Sociales).

HEGEL, Georg W. (1997 [1821]). Princípios da filosofia do direito. São Paulo: Martins Fontes.

HENNESSY, Rosemary \& INGRAHAM, Chris (1997). Materialism feminism: a reader in class, difference, and women's lives. New York: Routledge. HIRATA, Helena (2002). Nova divisão sexual do trabalho? São Paulo: Boitempo. HIRATA, Helena \& KERGOAT, Danièle (2007). "Novas configurações da divisão sexual do trabalho". Cadernos de Pesquisa, v. 37. n. 132, p. 595-609. HIRATA, Helena \& ZARIFIAN, Philippe (2009). "Trabalho (conceito de)", em HIRATA, Helena et al. (orgs.). Dicionário crítico do feminismo. São Paulo: Editora Unesp. 
JAMES, Selma (1997). "Introduction to 'The power of women and the subversion of the community' (1972)", em HENNESSY, R. \& INGRAHAM, C. (eds.). Materialism feminism: a reader in class, difference, and women's lives. New York: Routledge.

LASCH, Christopher (1999). A mulher e a vida cotidiana: amor, casamento e feminismo. Rio de Janeiro: Civilização Brasileira.

LUXEMBURGO, Rosa (1912). "Women's suffrage and class struggle". Disponível em: $<$ http://www.marxists.org/archive/luxemburg/1912/05/12. htm $>$. Acessado em set. 2015.

MARX, Karl (1969 [1843]). A questão judaica. São Paulo: Laemmert.

(1985 [1867]). O capital: crítica da economia política. v. 1, t. 2. São Paulo: Nova Cultural.

(1987). Teorias da mais-valia. v. 1. São Paulo: Bertrand Brasil.

(2004a). Capítulo VI inédito de "O capital". São Paulo: Centauro. (2004b [1844]). Manuscritos econômico-filosóficos. São Paulo: Boitempo.

MARX, Karl \& ENGELS, Friedrich (2003 [1844]). A sagrada família. São Paulo: Boitempo.

(2005 [1848]). Manifesto comunista. São Paulo: Boitempo. (2007 [1845-1846]). A ideologia alemã: crítica da mais recente filosofia alemã em seus representantes Feuerbach, B. Bauer e Stirner, e do socialismo alemão em seus diferentes profetas. São Paulo: Boitempo.

MITCHELL, Juliet (1966). "Women: the longest revolution". New Left Review, n. 40 , pp. 11-37.

(1971). Woman's estate. Maryland: Penguin Books.

(1977). La condición de la mujer. Barcelona: Editorial Anagrama.

MICHELET, Jules (1995 [1859]). A mulher. São Paulo: Martins Fontes.

MOLYNEUX, Maxine (1979). "Beyond the domestic labour debate". New Left Review, n. 116, pp. 1-27.

NOGUEIRA, Cláudia Mazzei (2006). O trabalho duplicado: a divisão sexual no trabalho e na reprodução. São Paulo: Expressão Popular.

NYE, Andrea (1995). Teoria feminista e as filosofias do homem. Rio de Janeiro: Record.

PERROT, Michele (2005). As mulheres e os silêncios da história. São Paulo: Edusc.

(2006). Os excluídos da história. Rio de Janeiro: Paz e Terra. 
PROUDHON, Pierre-Joseph (1858). "La pornocratie, ou les femmes dans les temps modernes”. Disponível em: <http://gallica.bnf.fr/ark:/12148/ bpt6k111425h.r=proudhon.langPT >. Acessado em 5 fev. 2011. SCOTT, Joan Walach (2002). A cidadã paradoxal: as feministas francesas e os direitos do homem. Florianópolis: Editora Mulheres.

TOLEDO, Cecília (2005). Mulheres: o gênero nos une, a classe nos divide. São Paulo: Sundermann.

VOGEL, Lise (1981). "Marxism and feminism: unhappy marriage, trial separation or something else?", em SARGENT, L. (ed.). Women and revolution: a discussion of the unhappy marriage of Marxism and feminism. Boston: South End Press.

\section{Resumo}

No cerne do movimento socialista, o debate acerca do trabalho doméstico e do cuidado com as crianças assumiu diferentes contornos. Embora muitas críticas tenham sido direcionadas a Marx e Engels por supostamente menosprezarem a importância do trabalho doméstico para a produção social e de idealizarem a família proletária como instância livre da opressão gerada pela propriedade privada, as discussões levantadas pelos defensores dos direitos das mulheres nas fileiras marxistas lograram desnaturalizar o papel ocupado por elas na divisão social de trabalho, questionando sua exclusão da esfera pública e seu confinamento no lar. Desse modo, atrelaram a possibilidade de emancipação feminina à socialização do trabalho doméstico e do cuidado com as crianças, no âmbito de uma sociedade sem classes. Palavras-chave: socialismo, gênero, crianças, trabalho doméstico, Estado, feminismo.

\section{Abstract}

At the core of the socialist movement, the debate on housework and child care took different shapes. Although much criticism had been directed at Marx and Engels for allegedly downplaying the importance of domestic work for social production and idealizing the proletarian family as a domain free of the oppression generated by private property, discussions raised by women's rights advocates within Marxist ranks managed to challenge naturalization of women's role in the social division of labor, questioning their exclusion from public sphere and their confinement to the household. Thus, they tied the possibility of women's emancipation to socialization of housework and child care within a classless society.

Keywords: socialism; gender; children; domestic labor; State; feminism.

Recebido em 2 de junho de 2015. Aprovado em 29 de setembro de 2015. 